\title{
Characterization of Minor Millets (Panicum sumatrense and Eleusine coracana) for Trait Related to Moisture Stress Tolerance
}

\author{
Patil Arun H. ${ }^{1}$, Mahima Dubey ${ }^{1}$, Abhinav Sao ${ }^{2}$ and Girish Chandel ${ }^{1 *}$
}

${ }^{1}$ Dept. of Plant Molecular Biology and Biotechnology, ${ }^{2}$ Dept. of Genetics and Plant Breeding, College of Agriculture, Indira Gandhi Krishi Vishwavidyalaya, Raipur, Chhattisgarh (492 012), India

\section{Corresponding Author}

Girish Chandel

e-mail: girishchandel@yahoo.com

\author{
Article History \\ Article ID: AR1867 \\ Received in $16^{\text {th }}$ March, 2018 \\ Received in revised form $28^{\text {th }}$ March, 2018 \\ Accepted in final form $4^{\text {th }}$ April, 2018
}

\begin{abstract}
Drought stress is one of the abiotic stresses which may alter plant growth, metabolism and yield. Water stress limits the growth, productivity and quality of agricultural crops in the world. Water Stress is not only due to the scarcity of water but also due other factors such as salinity, high temperatures and severe cold that make plants not able to absorb enough water from soil to grow well and this is called physiological drought that leads to a series of disorders in physiological and biochemical processes. Millets are resilient to extreme environmental conditions especially to inadequate moisture and are rich in nutrients. The aim of this research was to analyze the effects of water stress on relative water content, proline, soluble carbohydrates and chlorophyll content of minor millet genotypes under control conditions. The photosynthetic pigments like chlorophyll a, chlorophyll b and total chlorophyll decreased and the biochemical components like, proline, leaf protein and carbohydrate increased under water stress. In this study little millet genotypes showed minimum decrease in chlorophyll content and maximum increase in proline, protein and carbohydrate content when compared to the previously reported tolerant millet genotype. This study suggested the little millet (Panicum sumatrense) genotype RLM 37 having drought tolerant adaptive mechanism and better performance under water stress.
\end{abstract}

Keywords: Minor millet, water stress, relative water content, proline, protein

\section{Introduction}

Plant growth and development as well as crop production are highly influenced and sometimes limited by environmental conditions, such as drought, salinity and temperature stresses. Among these, drought stress is the most important environmental constrains to world agricultural production (Bray et al., 2000). Thus, an understanding of drought stress and water use in relation to plant growth is of importance for sustainable agriculture. Water stress not only affects the morphology but also severely affects the physiological metabolism of the plant. In response to various environmental stresses, plants have developed different physiological and biochemical mechanisms to adapt or tolerate stress (Rahnama and Ebrahimzadeh, 2005; Faical et al., 2009). Osmoregulation is one of the important biochemical phenomena in plants to cope up adverse environmental conditions. Osmotic adjustment in plants subjected to drought stress occurs by the accumulation of high concentrations of osmotically active compounds known as osmolytes such as proline, glycine betaine, soluble sugars, polyamines etc., in order to lower the osmotic potential (Rontein et al., 2002; Jouve et al., 2004).
Proline accumulates in many plant species under a broad range of stress conditions such as water shortage, salinity, extreme temperatures, and high light intensity. Proline is considered to be a compatible solute. Photosynthetic pigments are important to plants mainly for harvesting light and production of reducing power such as ATP and NADPH. Both the chlorophyll a (CHLa) and (CHLb) are prone to soil drying damages. Drought stress induced changes in the ratio of CHLa and CHLb and carotenoids (Farooq et al., 2009). The chlorophyll content decreased to a significant level at higher water deficits in plants (Kiani et al., 2008). Millets are examples of less-utilized crops with adaptation to marginal lands where they can withstand various stress conditions and contribute to sustainable low-input food production. Minor millets also called small millet are a group of grassy plants with short slender culm and small grains. They are categorized as coarse cereals and mainly form staple food for the tribal people where cultivation of major cereals like rice, wheat and maize is either not popular or fail to produce substantial yield (Chopra and Neelam, 2004). In India, small millets are cultivated in the semi-arid and hilly regions inhabited by traditional farmers. Finger millet is the principal crop amidst the small 
millets, occupying 60-70\% of the total area under small millet production globally, followed by kodo millet, foxtail millet, little millet, proso millet, and barnyard millet. Grains of small millets are extremely resistant to storage pests and can be stored for indefinite periods (Yenagi et al., 2010). Nutrition wise, grains of small millets are rich in micronutrients, particularly calcium and iron. They have high dietary fiber content, rich essential amino acids, and low glycemic index (Devi et al., 2011; Shobana et al., 2013). Minor millet is known for its great level of tolerance against drought, salinity and diseases. Water deficit affects the development, growth and yield in plant crop, but the tolerance crops to this stress varies remarkably. Changes in morphological, physiological, biochemical and molecular aspects are generally noted in response to drought stress. Understanding these responses to drought is important for screening tolerance of genotypes to water-limited conditions. The purpose of this research was to study water stress effect on some biochemical processes of minor millet cultivars, so that responses of these cultivars can be evaluated in resistance to drought stress.

\section{Materials and Methods}

\subsection{Plant material}

The experimental materials of the present investigation comprised of minor millet were planted in pots separately and maintained in green house at $28 \pm 2{ }^{\circ} \mathrm{C}$. Pots were watered normally (once per day) until the plants attain 21 day period. The 21-day-old seedlings were subjected to water stress. Water was withdrawn from pot on $21^{\text {st }}$ up to $29^{\text {th }}$ days. Samples were harvested on $30^{\text {th }}$ days from both control and water stressed plants in liquid nitrogen and stored at $-80^{\circ} \mathrm{C}$.

\subsection{Relative water content of leaf (RWC \%)}

RWC was measures for both stress and control plant leaves. Measurements of RWC were made between 11:00 to 13:00 hours after the dew had dried. One fully extended next to flag leave per plot was sampled in pre-weighed centrifuge tubes. Immediately after cutting at the base of lamina, leaves were sealed in pre-weighed centrifuge tubes and quickly transferred to the laboratory. Fresh weights (FW) of leaves were determined. Turgid weight (TW) were obtained after soaking leaves in distilled water in test tubes for 4 to $6 \mathrm{hr}$ at room temperature (about $20^{\circ} \mathrm{C}$ ) and under the low light conditions of laboratory. After soaking, leaves were quickly and carefully blotted dry with tissue paper in preparation for determining turgid weight. Dry weights (DW) were obtained after oven drying the leaf samples for $48 \mathrm{hr}$ at $70^{\circ} \mathrm{C}$. The RWC was calculated based on the formula suggested by Barr and Weatherley (1962) as follows:

RWC\%=(FW-DW/TW-DW $) \times 100$

Where

$F W=$ fresh weights of leaf taken immediately after excision

TW=Turgid weight of leaf

$\mathrm{DW}=$ Dry weight of leaf drying at $70{ }^{\circ} \mathrm{C}$ for $48 \mathrm{~h}$.

\subsection{Measurement of proline}

Proline content was estimated following the method described by Bates et al. (1973).

Express the proline content on fresh weight basis as follows: $\mu$ moles per $\mathrm{g}$ tissue $=\frac{\mu \mathrm{g} \text { proline } \mathrm{ml}^{-1} \times \mathrm{ml} \text { toluene }}{115.5} \times \frac{5}{\text { sample-1 }}$

\subsection{Estimation of total carbohydrates}

Total carbohydrates in the leaves and seeds were determined by phenol sulphuric acid method proposed by Krishnaveni et al. (1984). For the estimation, $100 \mathrm{mg}$ of tissue control and stress plants was weighed. The tissue was hydrolyzed by adding $5 \mathrm{ml} 2.5 \mathrm{~N} \mathrm{HCl}$ and boiling in hot water bath for three hours. After cooling, it was neutralized using solid sodium carbonate until effervescence ceases. The final volume was made to $100 \mathrm{ml}$ and centrifuged. From this sample, 0.1 and $0.2 \mathrm{ml}$ was pipette out in two separate test tubes. The volume of the test tube was made to $1 \mathrm{ml}$ by using distilled water. To the test tubes, $1 \mathrm{ml}$ phenol and $5 \mathrm{ml} 96 \% \mathrm{H}_{2} \mathrm{SO}_{4}$ was added. The tubes were kept for 10 minutes and shaken well. These test tubes were kept in hot water bath at $20-30{ }^{\circ} \mathrm{C}$ for 20 minutes. The absorbance was taken at $490 \mathrm{~nm}$ after cooling by using the mixture of $1 \mathrm{ml}$ water, $1 \mathrm{ml}$ phenol and $96 \% \mathrm{H}_{2} \mathrm{SO}_{4}$.

\subsection{Estimation of protein content}

The total leaf protein content of eighteen rice genotypes was estimated as per the method given by Lowry et al. (1951).

\subsection{Chlorophyll estimation}

Chlorophyll were extracted from the leaves and estimated by the method of Arnon (1949).

Chlorophyll content was calculated using the formula of Arnon as follows:

Total chlorophyll $(\mathrm{mg} / \mathrm{ml})=(0.0202) \times($ A.645 $)+(0.00802) \times$ (A.663)

Chlorophyll 'a' $(\mathrm{mg} / \mathrm{ml})=(0.0127) \times($ A.663 $)-(0.00269) \times($ A.645 $)$ Chlorophyll 'b' $(\mathrm{mg} / \mathrm{ml})=(0.0229) \times($ A.645 $)-(0.00468) \times($ A.663 $)$.

The values were expressed in milligram per gram fresh weight.

\subsection{Estimation of chlorophyll stability index}

The chlorophyll stability index (CSI) of eighteen rice genotypes was determined according to Sairam et al. (1997) and calculated as follows:

$$
\mathrm{CSI}=\frac{\text { (Total chlorophyll under stress) }}{\text { (Total chlorophyll under control) }} \times 100
$$

\subsection{Statistical analysis}

The OPSTAT software developed at BHU was applied for statistical analysis.

\section{Results and Discussion}

\subsection{Effect of water stress on relative water content of leaf (RWC \%)}

Water stress treatment produced a significant decline in 
relative water content of leaf (RWC) among seven millet genotypes. The mean RWC was recorded as $84.711 \%$ (ranged from $81.709-87.040 \%$ ) at control condition and $32.502 \%$ (ranged from 20.939-49.289\%) under stress condition (Table $1,2)$. Among the seven genotypes, higher RWC was recorded in little millet genotype BL 4 (87.040\%) and lowest RWC was observed in OLM $203(81.709 \%)$ under control condition and higher RWC was recorded in little millet genotype RLM $37(49.289 \%)$ and lowest RWC was observed in PR 1014 (20.939\%) under stress condition. Minimum decrease in RWC content over control were recorded in RLM 37 (1.699 fold), and GPU 67 (1.841 fold) under water stress condition. Schonfeld et al. (1988) expressed with increase of drought stress of wheat, RWC decrease and usually but not always,

\begin{tabular}{|c|c|c|c|c|c|c|c|}
\hline \multirow[t]{2}{*}{ Genotype } & RWC Control & $\begin{array}{l}\text { Proline } \\
\text { control }\end{array}$ & $\begin{array}{c}\text { Carbohydrate } \\
\text { control }\end{array}$ & $\begin{array}{l}\text { Protein } \\
\text { control }\end{array}$ & $\begin{array}{c}\text { Chlorophyll } \\
\text { a Control }\end{array}$ & $\begin{array}{l}\text { Chlorophyll b } \\
\text { control }\end{array}$ & $\begin{array}{l}\text { Total chloro- } \\
\text { phyll control }\end{array}$ \\
\hline & Mean $\pm S . E$. & Mean \pm S.E. & Mean $\pm S . E$. & Mean \pm S.E. & Mean \pm S.E. & Mean \pm S.E. & Mean $\pm S . E$. \\
\hline RLM 37 & $83.743 \pm 0.000$ & $0.029 \pm 0.007$ & $38.016 \pm 0.299$ & $0.011 \pm 0.001$ & $0.916 \pm 0.002$ & $0.435 \pm 0.003$ & $1.350 \pm 0.006$ \\
\hline BL 4 & $87.040 \pm 0.260$ & $0.686 \pm 0.006$ & $53.819 \pm 0.209$ & $0.092 \pm 0.000$ & $0.938 \pm 0.003$ & $0.641 \pm 0.004$ & $1.580 \pm 0.007$ \\
\hline MM 10 & $86.928 \pm 0.470$ & $0.591 \pm 0.006$ & $38.359 \pm 0.238$ & $0.095 \pm 0.001$ & $0.856 \pm 0.002$ & $0.417 \pm 0.003$ & $1.273 \pm 0.005$ \\
\hline OLM 203 & $81.709 \pm 0.337$ & $0.262 \pm 0.008$ & $26.018 \pm 0.214$ & $0.096 \pm 0.000$ & $0.928 \pm 0.002$ & $0.459 \pm 0.004$ & $1.387 \pm 0.007$ \\
\hline GPU 67 & $84.186 \pm 0.233$ & $0.100 \pm 0.006$ & $18.717 \pm 0.297$ & $0.109 \pm 0.002$ & $2.607 \pm 0.003$ & $1.546 \pm 0.000$ & $4.153 \pm 0.003$ \\
\hline BR 36 & $84.309 \pm 0.507$ & $0.063 \pm 0.007$ & $27.492 \pm 0.305$ & $0.010 \pm 0.001$ & $1.379 \pm 0.002$ & $1.176 \pm 0.003$ & $2.555 \pm 0.004$ \\
\hline PR 1014 & $85.065 \pm 0.047$ & $0.539 \pm 0.008$ & $21.802 \pm 0.178$ & $0.271 \pm 0.002$ & $1.087 \pm 0.002$ & $0.435 \pm 0.004$ & $1.522 \pm 0.006$ \\
\hline Mean & 84.711 & 0.324 & 32.032 & 0.098 & 1.244 & 0.730 & 1.974 \\
\hline Minimum & 81.709 & 0.029 & 18.717 & 0.010 & 0.856 & 0.417 & 1.273 \\
\hline Maximum & 87.040 & 0.686 & 53.819 & 0.271 & 2.607 & 1.546 & 4.153 \\
\hline $\mathrm{CD}(p=0.05)$ & 0.980 & 0.022 & 0.775 & 0.005 & 0.007 & 0.010 & 0.017 \\
\hline SEm \pm & 0.320 & 0.007 & 0.253 & 0.001 & 0.002 & 0.003 & 0.006 \\
\hline SEd \pm & 0.452 & 0.010 & 0.358 & 0.002 & 0.003 & 0.005 & 0.008 \\
\hline C.V. & 0.654 & 3.749 & 1.368 & 2.624 & 0.334 & 0.780 & 0.485 \\
\hline \multirow[t]{2}{*}{ Genotype } & RWC Stress & $\begin{array}{l}\text { Proline } \\
\text { stress }\end{array}$ & $\begin{array}{c}\text { Carbohydrate } \\
\text { stress }\end{array}$ & $\begin{array}{c}\text { Protein } \\
\text { stress }\end{array}$ & $\begin{array}{c}\text { Chlorophyll } \\
\text { a stress }\end{array}$ & $\begin{array}{c}\text { Chlorophyll b } \\
\text { stress }\end{array}$ & $\begin{array}{l}\text { Total chloro- } \\
\text { phyll stress }\end{array}$ \\
\hline & Mean \pm S.E. & Mean \pm S.E. & Mean \pm S.E. & Mean \pm S.E. & Mean \pm S.E. & Mean \pm S.E. & Mean \pm S.E. \\
\hline RLM 37 & $49.289 \pm 0.297$ & $0.496 \pm 0.009$ & $97.731 \pm 0.298$ & $0.246 \pm 0.005$ & $0.452 \pm 0.003$ & $0.310 \pm 0.003$ & $0.762 \pm 0.006$ \\
\hline BL 4 & $28.452 \pm 0.227$ & $0.723 \pm 0.005$ & $61.155 \pm 0.299$ & $0.241 \pm 0.004$ & $0.123 \pm 0.003$ & $0.143 \pm 0.006$ & $0.266 \pm 0.003$ \\
\hline MM 10 & $31.673 \pm 0.375$ & $2.083 \pm 0.006$ & $60.537 \pm 0.240$ & $0.320 \pm 0.002$ & $0.229 \pm 0.002$ & $0.173 \pm 0.004$ & $0.401 \pm 0.006$ \\
\hline OLM 203 & $21.468 \pm 0.574$ & $0.822 \pm 0.005$ & $39.867 \pm 0.299$ & $0.313 \pm 0.001$ & $0.436 \pm 0.002$ & $0.462 \pm 0.004$ & $0.898 \pm 0.005$ \\
\hline GPU 67 & $45.739 \pm 0.286$ & $0.249 \pm 0.007$ & $30.029 \pm 0.297$ & $0.257 \pm 0.003$ & $2.309 \pm 0.001$ & $1.233 \pm 0.003$ & $3.540 \pm 0.004$ \\
\hline BR 36 & $29.956 \pm 0.039$ & $1.067 \pm 0.008$ & $38.839 \pm 0.280$ & $0.177 \pm 0.018$ & $1.09 \pm 0.003$ & $0.406 \pm 0.003$ & $1.495 \pm 0.006$ \\
\hline PR 1014 & $20.939 \pm 0.306$ & $2.719 \pm 0.005$ & $44.358 \pm 0.240$ & $0.352 \pm 0.003$ & $0.751 \pm 0.003$ & $0.306 \pm 0.004$ & $1.057 \pm 0.007$ \\
\hline Mean & 32.502 & 1.166 & 53.217 & 0.272 & 0.770 & 0.433 & 1.203 \\
\hline Minimum & 20.939 & 0.249 & 30.029 & 0.177 & 0.123 & 0.143 & 0.266 \\
\hline Maximum & 49.289 & 2.719 & 97.731 & 0.352 & 2.309 & 1.233 & 3.540 \\
\hline $\mathrm{CD}(p=0.05)$ & 1.027 & 0.021 & 0.858 & 0.022 & 0.007 & 0.012 & 0.017 \\
\hline SEm \pm & 0.335 & 0.007 & 0.280 & 0.007 & 0.002 & 0.004 & 0.005 \\
\hline SEd \pm & 0.474 & 0.01 & 0.396 & 0.01 & 0.003 & 0.006 & 0.008 \\
\hline C.V. & 1.787 & 1.003 & 0.912 & 4.653 & 0.516 & 1.628 & 0.78 \\
\hline
\end{tabular}


in drought stress conditions, the cultivars that are resistant to drought have more RWC. Relative water content (RWC) of leaves has been reported as direct indicator of plant water contents under water deficit conditions (Lugojan and Ciulca, 2011). Under water stress condition decrease in water status and osmotic potential in plants is the ultimate outcome of lower relative water content. Osmoregulation mechanism plays a phenomenal role in preserving turgor pressure which helps in soil water absorption and continue plant metabolic activities for its survival. In this study, little millet genotype RLM 37 showed minimum decrease in relation water content which indicates their comparable potential for drought tolerance with respect to known drought tolerant finger millet genotypes GPU 67.

\subsection{Effect of drought stress on leaf proline content}

Accumulation of proline as an osmolyte under water stress was observed in seven different millet genotypes. Mean leaf proline content was found to be $0.324 \mu \mathrm{mol} \mathrm{g}^{-1}$ fresh weight of leaf tissue (ranged from $0.029 \mu \mathrm{mol} \mathrm{g}^{-1}$ f.wt.- $0.686 \mu \mathrm{mol}$ $\mathrm{g}^{-1}$ f.wt.) at control condition, which increased to $1.166 \mu$ $\mathrm{mol} \mathrm{g}^{-1}$ fresh weight under water stress (ranged from 0.249 $\mu$ mol g-1 f.wt.- $2.719 \mu$ mol g-1 f.wt.), (Table 1, 2). Highest increase in leaf proline content over control was recorded in little millet genotype RLM 37 (17.103 fold) followed by finger millet genotype BR 37 (16.937 fold) under water stress. In general, proline content of leaves increased with the decline in irrigation water, suggesting that the production of proline is probably a common response of millet under drought conditions. The role of proline in adaptation and survival of plants under has been well documented by Watanabe et al. (2000) and Saruhan et al. (2006). Proline is one of the most studied solutes and high proline content in plants under water stress is frequently observed in several species (Clifford et al., 1998; Bajji et al., 2001) and may act as a regulatory or signaling molecule to activate multiple responses that are part of the adaptation process (Maggio et al., 2002; Claussen, 2005). Osmotic adjustment through the accumulation of cellular solutes, such as proline, has been suggested as one of the possible means for overcoming osmotic stress caused by the loss of water (Caballero et al., 2005). Lobato et al. (2011) reported that the accumulation of proline and free amino acids in soybean (Glycine max cv. Sambaiba) leaves were increased under water deficit 67 and 388.1\%, respectively. Teixeira and Pereira (2006) indicated that proline content significantly increased in all potato organs in response to the stress conditions. This increase was more remarkable in roots and tubers than in the leaves. High levels of proline enable the plant to maintain low water potentials causing the accumulation of compatible osmolytes that allows additional water to be taken up from the environment, thus buffering the immediate effect of water deficit within the organism (Mousa and Abdel-Aziz, 2008). In this study on the basis of accumulation of leaf proline content under water stress condition little millet genotype RLM 37 and finger millet genotype BR 36 was found to be maximum compared to tolerant genotype GPU 67 hence were identified as potential drought tolerant genotypes.

\subsection{Effect of drought stress on carbohydrate}

The observation of carbohydrate content under control and stress condition showed that the carbohydrate increases significantly with prolongation of water stress. Mean carbohydrate content of the minor millet genotype was found to be $32.032 \mathrm{mg} \mathrm{g}^{-1}$ f.wt (ranged from $18.717 \mathrm{mg} \mathrm{g}^{-1}$ f.wt.- $53.819 \mathrm{mg} \mathrm{g}^{-1}$ f.wt.) at control condition, which increased further to $53.217 \mathrm{mg} \mathrm{g}^{-1} \mathrm{f}$.wt under water stress (ranged from

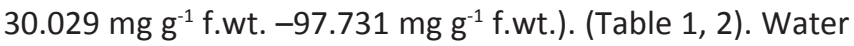
stress induced highest increase in carbohydrate content was obtained in little millet genotype RLM 37 (2.571 fold) followed by finger millet genotype PR 1014 (2.035 fold) when compared with tolerant genotype GPU 67. The accumulation of sugars in response to drought is quite well documented (Izanloo et al., 2008; Watanabe et al., 2000). Soluble sugars may function as a typical osmoprotectant, stabilizing cellular membranes and maintaining turgor pressure. Gene ontology attributes such as proline and soluble sugar accumulations were highly enriched in the drought-up-regulated genes, suggesting that those metabolic pathways are important in responses to drought stress. Indeed, the importance of many of these pathways to drought tolerance has been empirically supported by transgenic experiments (Umezava et al., 2006). Proline and total soluble sugar content in the leaves was significantly $(p<0.05)$ increased due to the increase in the level of drought stress. The differences in the responses to drought stress among the nine selected corn cultivars suggested that each cultivar has different ability to synthesis proline and total soluble sugar with an increase in drought stress treatment (Hermalina et al., 2014).

\subsection{Effect of drought stress on protein content}

The protein content of seven millet genotypes was recorded under control and water stress conditions. The mean soluble protein content was found to be $0.098 \mathrm{mg} \mathrm{g}^{-1} \mathrm{f}$.wt. (ranged from $0.010-0.271 \mathrm{mg} \mathrm{g}^{-1}$ f.wt.) in control condition, which increased to $0.271 \mathrm{mg} \mathrm{g}^{-1} \mathrm{f} . \mathrm{wt}$. (ranged from $0.177-0.352$ $\mathrm{mg} \mathrm{g}^{-1} \mathrm{f}$.wt.) under stress condition. (Table 1,2). Water stress induced highest increase in protein content was obtained in little millet genotype RLM 37 (22.36 fold) followed by finger millet genotype BR 36 (17.70 fold) when compared with tolerant genotype GPU 67. Chinoy et al. (1974) who also reported high protein content in drought stressed rice plant. Ashraf and Foolad (2005) had reported that higher protein content in tolerant genotypes under water stress condition is due to higher DNA and RNA content, which stimulate synthesis and inhibit protein decomposition. According to Ahmad et al soluble sugars and the protein content of the leaves from water stressed plants was significantly higher than the irrigated control. Comparison within each stress period showed that the protein levels were significantly higher at 
all stress periods than the controls. In this study little millet genotype RLM 37 was found to be maximum protein content compared to tolerant genotype GPU 67. Increases in protein suggest that under water stress conditions synthetic activity is enhanced to accommodate increased metabolic activity for maintaining the osmotic balance.

\subsection{Effect of drought stress on chlorophyll content}

The chlorophyll content of seven millet genotypes was recorded under control and water stress conditions. A significant decrease in chlorophyll content (chlorophyll a, b and total chlorophyll) was observed in seven millet genotypes under water stress conditions (Table 1, 2).

\subsubsection{Chlorophyll a content}

The mean chlorophyll a content was recorded to be 1.244 $\mathrm{mg} \mathrm{g}^{-1}$ leaf tissue. It ranged from $0.856 \mathrm{mg} \mathrm{g}^{-1}$ in little millet genotype MM 10 to $2.607 \mathrm{mg} \mathrm{g}^{-1}$ leaf tissue in finger millet genotype GPU 67 under control condition. While mean chlorophyll content under stress was found to be $0.770 \mathrm{mg} \mathrm{g}^{-1}$ leaf tissue which ranged from 0.123 in little millet genotype $B L$ 4 to $2.309 \mathrm{mg} \mathrm{g}^{-1}$ leaf tissue in finger millet genotype GPU 67 . (Table 1, 2). Minimum fold decrease in chlorophyll a content was recorded in finger millet genotype GPU 67 (1.129 Fold) followed by BR 36 (1.265 fold).

\subsubsection{Chlorophyll b content}

The mean chlorophyll b content was recorded to be $0.730 \mathrm{mg}$ $\mathrm{g}^{-1}$ leaf tissue. It ranged from 0.417 in little millet genotype $\mathrm{MM}$ 10 to $1.546 \mathrm{mg} \mathrm{g}^{-1}$ leaf tissue in finger millet genotype GPU 67 under control condition. Under stress, the mean chlorophyll b content was found to be $0.433 \mathrm{mg} \mathrm{g}^{-1}$ leaf tissue. This was in the range of 0.143 in little millet genotype $B L 4$ to $1.223 \mathrm{mg} \mathrm{g}^{-1}$ leaf tissue in finger millet genotype GPU 67 under water stress condition (Table 1, 2). Out of seven genotypes under study, minimum decrease was recorded in little millet genotype OLM 203 ( 0.994 fold) followed by finger millet genotype GPU 67 (1.254 fold).

\subsubsection{Total chlorophyll content}

At control condition the mean total chlorophyll content was found to be $1.974 \mathrm{mg} \mathrm{g}^{-1}$ leaf tissue. It ranged from 1.273 (MM 10) to $4.153 \mathrm{mg} \mathrm{g}^{-1}$ leaf tissue (GPU 67) which decreased to $1.203 \mathrm{mg} \mathrm{g}^{-1}$ leaf tissue (ranged from $0.266-3.540 \mathrm{mg} \mathrm{g}^{-1}$ leaf tissue) under water stress condition (Table 1, 2). Out of seven genotypes, minimum decrease were recorded in finger millet GPU 67 (1.173 fold) followed by PR 1014 (1.440 fold) and BR 36 (1.709 fold) hence were considered as potential drought tolerant genotypes. The chlorophyll was declined from well watered (control) condition to severe drought stress (13 DID) and plant pigment was increased by the age of maturity in plant (Paul et al., 2013). Manirannan et al. (2007) detected a depression in CHL a and $\mathrm{b}$ and TC in Helianthus annuus $\mathrm{L}$. under water stress. According to Poljakoff and Gale (1975), the ability to synthesize more chlorophyll under water stress is a good criterion for the species tolerant to drought. In this study finger millet genotype showed minimum decrease in chlorophyll content that suggested their tolerance mechanism under water stress.

\subsection{Effect of drought stress on chlorophyll stability index (CSI\%)}

Water stress induced decreasing trend in chlorophyll stability index (\%) was observed in seven millet genotypes. A significant difference $(p<0.05)$ for chlorophyll stability index (CSI) was observed among seven millet genotypes under water stress condition. The mean chlorophyll stability index was found to be $54.686 \%$ (ranged from $16.840-85.258 \%$ ) under water stress. Among seven millet genotypes, lower decrease in CSI (\%) was obtained in BL 4 (16.840\%). The higher CSI\% obtained in tolerant finger millet genotype GPU 67 followed by PR 10 $14(69.453 \%)$ indicated enhanced ability of identified millet genotypes to withstand water stress condition.

\section{Conclusion}

Plants in drought stress time make changes in some of their physiological and biochemical features. Accumulations of soluble carbohydrates, proline and protein increased under water stress and the genotypes that have more RWC and chlorophyll content are more resistant to drought stress. Our results represented that the little millet genotype RLM 37 showed minimum decrease in RWC and maximum increase in proline, carbohydrate and protein which indicates their comparable potential for drought tolerance with respect to tolerant genotype.

\section{Acknowledgment}

Seed material provided by ZARS, Jagdalpur, Department of Genetic and plant Breeding and Department of Biotechnology, Ministry of Science and Technology, Govt. of India for providing the financial support are thankfully acknowledged.

\section{References}

Arnon, D.I., 1949. Copper enzyme polyphenoloxides in isolated chloroplast in Beta Vulgaris. Plant physiology 24, 1-15.

Ashraf, M., Foolad, M.R., 2005. Role of Glycine Betaine and Proline in Improving Plant Abiotic Stress Resistance. Environmental and Experimental Botany 59(2), 206-216. doi:10.1016/j.envexpbot 2005.12.006.

Bajji, M., Lutts, S., Kinet, J.M., 2001. Water deficit effects on solute contribution to osmotic adjustment as a function of leaf ageing in three durum wheat (Triticum durum Desf.) cultivars performing differently in arid conditions. Plant Science 160, 669-681.

Barrs, H.D., Weatherley, P.E., 1962. A Re-examination of the relative turgidity techniques for estimating water deficits in leaves. Australian Journal of Biological Sciences 15, 413-428.

Bates, L., Waldren, R.P., Teare, I.D., 1973. Rapid determination of free proline for water-stress studies. Plant and Soil 
39, 205-207.

Bray, E.A., Bailey-Serres, J., Weretilnyk, E., 2000. Responses to abiotic stresses. In: Gruissem, W., Buchannan, B., Jones, R. (Eds.), Biochemistry and Molecular Biology of Plants. American Society of Plant Physiologists, Rockville, MD, 1158-1249.

Caballero, J.I., Verduzco, C.V., Galan, J., Jimenz, E.S.D., 2005. Proline accumulation as a symptom of drought stress in maize: A tissue differentiation requirement. Journal of Experimental Botany 39(7), 889-897.

Chinoy, J.J., Singh, Y.D., Gurumurti, K., 1974. Biosynthesis of ascorbic acid and mobilization patterns of macromolecules during water stressing germinating ciser seedling. Biology Plant 16, 301-307.

Chopra, K., Neelam, M., 2004. Common health problems encountered by the tribal community in bastar district. Health and Population-Perspectives and Issues 27, 40-48.

Claussen, W., 2005. Proline as a measure of stress in tomato plants. Plant Science 168, 241-248.

Clifford, S.C., Arndt, S.K., Corlett, J.E., Joshi, S., Sankhla, N., Popp, M., Jones, H.G., 1998. The role of solute accumulation, osmotic adjustment and changes in cell wall elasticity in drought tolerance in Ziziphus mauritiana (Lamk.). Journal of Experimental Botany 49, 967-977.

Devi, P.B., Vijayabharathi, R., Sathyabama, S., Malleshi, N.G., Priyadarisini, V.B., 2011. Health benefits of finger millet (Eleusine coracana L.) polyphenols and dietary fiber: a review. Journal of Food Science and Technology. Doi 10.1007/s13197-011-0584.

Faical, B., Imen, A., Kaouther, F., Moez, H., Habib, K., Khaled, M., 2009. Physiological and molecular analyses of seedlings of two Tunisian durum wheat (Triticum turgidum L. subsp. Durum (Desf) varieties showing contrasting tolerance to salt stress. Acta Physiol Plant 31, 145-154.

Farooq, M., wahid, A., kobayashi, N., Fujita, D., Basra, S.M.A., 2009. Plant drought stress: effect mechanism and management. Agronomy for sustainable Development 29, 185-212.

Hermalina, S., Karuwal, R.L., 2014. Proline and total soluble sugar content at the vegetative phase of six corn cultivars from Kisar Island Maluku, grown under drought stress conditions. International Journal of Plant Biology. volume 6, 6071

Izanloo, A., Condon, A.G., Langridge, P., Tester, M., Schnurbusch, T., 2008. Different mechanisms of adaptation to cyclic water stress in two South Australian bread wheat cultivars. Journal of Experimental Botany 59, 3327-3346.

Jouve, L., Hoffmann, L., Hausman, J.F., 2004. Polyamine, carbohydrate, and proline content changes during salt stress exposure of aspen (Populus tremula L.): involvement of oxidation and osmoregulation metabolism. Plant Biology 6, 74-80.

Kiani, S.P., Maury, P., Sarrafi, A., Grieu, P., 2008. QTL analysis of chlorophyll fluorescence parameters in sunflower (Helianthus annuus L.) under well watered and water stress conditions. Plant Science 175, 565-573.

Krishnaveni, S., Theymoli, Balasubramanian., Sadasivam, S., 1984. Phenol sulphuric acid method. Food chem. 15-229.

Lobato, A.K.S., Oliveira Neto, C.F., Costa, R.C.L., Santos Filho, B.G., Cost, R.C.L., Cruz, F.J.R., Neves, H.K.B., Lopes, M.J.S., 2011. Physiological and biochemical behavior in soybean (Glycine max cv. Sambabia) plants under water deficit. Australian Journal of Crop Science 5(1), 55-60.

Lowry, O.H., Rosenbrough, N.J., Farr, A.L., Randall, R.J., 1951. Protein measurement with the Folin Phenol reagent. Journal of Biological Chemistry 193, 265-275.

Lugojan, C., Ciulca, S., 2011. Evaluation of relative water content in winter wheat. Journal of Horticulture Forestry Biotechnology 15, 173-177.

Maggio, A., Miyazaki, S., Veronese, P., Fujita, T., Ibeas, J.I., Damsz, B., Narasimhan, M.L., Hasegawa, P.M., Joly, R.J., Bressan, R.A., 2002. Does proline accumulation play an active role in stress-induced growth reduction? The Plant Journal., 31, 699-712.

Manirannan, P., Abdul Jaleel, C., Sankar, B., Kishorekumar, A., Somasundaram, R., Lakshmanan, G.M., Panneerselvam, R., 2007. Growth, biochemical modifications and proline metabolism in Helianthus annuus L. as induced by drought stress. Colloids and Surf B: Biointerfaces 59, 141-149.

Mousa, H.R., Abdel-Aziz, S.M., 2008. Comparative response of drought tolerant and drought sensitive maize genotypes to water stress. Australian Journal of Crop Science 1, 31-36.

Paul, A., Panneerselvam, R., 2013. Osmolyte accumulation, photosynthetic pigment and growth of Setaria italica (L.) P. Beauv. under drought stress Asian Pacific Journal of Reproduction 2(3), 220-224.

Poljakoff, M., and Gale, J., 1975. Plants in saline environments. Springer Verlag, Belin (Heidelberg).

Rahnama, H., Ebrahimzadeh, $\mathrm{H} ., 2005$. The effect of $\mathrm{NaCl}$ on antioxidant enzyme activities in potato seedling. Biologia Plantarum 49, 93-97.

Rontein, D., Basset, G., Hanson, A.D., 2002. Metabolic engineering of osmoprotectant accumulation in plants. Metabolic Engineering 4, 49-56.

Sairam, R.K., Deshmukh, P.S., Shukla, D.S., 1997. Tolerance of drought and temperature stress in relation to increased antioxidant enzyme activity in wheat. Journal of Agronomy and Crop Science 178, 171-178.

Saruhan, N., Terzi, R, Kadioglu, A., 2006. The effects of exogenous polyamines on some biochemical changes during drought stress in Ctenanthe setosa. Acta Biologica Hungarica 57, 221-229.

Schonfeld, M.A., Johnson, R.C., Carver, B.F., Mornhinweg, 
D.W., 1988. Water relations in winter wheat as drought resistance indicators. Crop Science 28, 526-531.

Shobana, S., Krishnaswamy, K., Sudha, V., Malleshi, N.G., Anjana, R.M., Palaniappan, L., Mohan, V., 2013. Finger millet (Ragi, Eleusine coracana L.): a review of its nutritional properties, processing, and plausible health benefits. Advances in Food Nutrition Research. 69, 1-39.

Teixeira, J., Pereira, S., 2006. High salinity and drought act on an organ-dependent manner on potato glutamine synthetase expression and accumulation. Journal of Experimental Botany 60, 121-126.

Umezawa, T., Fujita, M., Fujita, Y., Yamaguchi Shinozaki, K., Shinozaki, K., 2006. Engineering drought tolerance in plants: discovering and tailoring genes to unlock the future. Current Opinion in Biotechnology 17, 113-122.

Watanabe, S., Kojima, K., Ide, Y., Satohiko, S., 2000. Effects of saline and osmotic stress on proline and sugar accumulation in Populus euphratica in vitro. Plant Cell, Tissue and Organ Culture 63,199-206.

Yenagi, N.B., Handigol, J.A., Ravi, S.B., Mal, B., Padulosi, S., 2010. Nutritional and technological advancements in the promotion of ethnic and novel foods using the genetic diversity of minor millets in India. International Journal of food and nutritional science. 